\title{
MJN EMPLOYEE RETENTION OF REGISTERED NURSES IN A MALAYSIAN PRIVATE HOSPITAL: A PILOT STUDY
}

\author{
Fong Chin Mun*, S. M. Ferdous Azam, Ahmad Rasmi Suleiman Albattat \\ Post Graduate Centre, Management and Science University, University Drive, Off Persiaran Olahraga, \\ Selangor, Malaysia \\ *Corresponding Author's Email: fongchinmun@gmail.com
}

\begin{abstract}
Background: Employee retention among registered nurses working in a hospital is one of the most challenging existing global issues. This study aims to develop a pilot study for employee retention of registered nurses working in medical and medical wards in one of the tertiary hospitals in Kuala Lumpur, Malaysia. Methods: The pilot study was performed after the approval of Ethics Committee. Selfadministered questionnaires were distributed to 30 respondents with informed consent. This study measures the variables of family social support, employee engagement, working environment and condition, manager and peer support and development opportunities on job satisfaction as a mediator to dependent variable, employee retention. Descriptive analysis and reliability analysis were used to analyse the data via statistical analysis in IBM SPSS version 23.0. Results 100\% of the registered nurses working in medical surgical wards were females and $50 \%$ of them were Malays. $70 \%$ of them were 30 years old and above. $66.7 \%$ nursing working experience in the current hospital fall in between 1 month to 5 years and $73.3 \%$ average working hours per day were in between $7-10$ hours. The Cronbach's alpha in each variable is ranging from 0.882 to 0.950 . The overall construct of Cronbach's alpha is 0.972 . Conclusion: The reliability analysis findings affirm that family social support, employee engagement, working environment and condition, manager and peer support, development opportunities, job satisfaction and employee retention are having high level of internal consistency prior proceeding to actual study.
\end{abstract}

Keywords: Pilot Study; Registered Nurses; Private Hospital

\section{INTRODUCTION}

Nursing profession is a high demand profession that requires individual capacity to cope and manage under intense physical and emotional dynamics in the workplace (Permarupan et al., 2020). New employees can be costly, as new hires need to be trained and mould to be familiar with the policies, procedures and operation in a healthcare setting (Antwi \& Bowblis, 2018). Retention of registered nurses could be considered as one of the most challenging elements in healthcare organisations globally (Bobbio \& Manganelli, 2015). Due to the nurses' boundary-spanning roles, the task of today has become more demanding and competitive in contributing to the health and wellbeing of society in Malaysia (Othman \& Nasurdin, 2019).

\section{METHODOLOGY}

The purpose of this research is to study the relationship between family social support, employee engagement, working environment and condition, manager and peer support and development opportunities as independent variables, job satisfaction as mediating variable and employee retention as dependent variable. The data was collected via survey questionnaires to all of the respondents.

A cross-sectional study was conducted in one of the private hospitals in Kuala Lumpur, Malaysia. The population of the study includes registered nurses who were working in medical and surgical wards. Total 30 sample size were taken as pilot study before proceeding to the actual study. The response rate reached $100 \%$. Pilot study was conducted to determine the feasibility of using a survey questionnaire and data collection processes (Fraser et al., 2018). The objective of the pilot study is to increase the probability of success in the main study by testing the viability of the study in term of 
content validity (Fraser et al., 2018).

\section{Statistical Analysis}

Statistical analysis was performed by IBM SPSS version 23.0. Descriptive analysis was performed for demographic profile. Reliability analysis was done to measure the internal consistency in each and overall construct.

\section{Ethics Statement}

This study was conducted after approved by the Pantai Hospital Kuala Lumpur Research and Ethics Committee (PHKL REC Approval Number: PHKL-EC2020-0004). Informed consent was obtained from all the participants before questionnaire administration.

\section{Instrument}

The instrument for this research was in a form of questionnaire. The questionnaire was comprised of four categories, which are section A, B, C and D (Table 1). Section A was in a nominal and ordinal scale to form a questionnaire that consist of 5 items related to respondents' demographic profiles such as gender, race, age, duration of working experience and average working hours per day. The nominal scales are used to identify gender and race. The ordinal scales were used to determine the nurses' age, duration of working experience and average of working hours per day. Section B comprised of items that were related to independent variables that include family social support, employee engagement, working environment and condition, manager and peer support and development opportunities. Section C was related to mediating variable on job satisfaction and lastly section $\mathrm{D}$ comprised of items related to dependent variable, employee retention. Section B, C and D are using interval scale to determine on the independent variables, mediating variable and dependent variable which were measured by using five-point Likert scales which are one (strongly disagree) to five (strongly agree).

\section{Table 1: Summary of Questionnaires Layout}

\begin{tabular}{|c|c|c|c|}
\hline Section & Variables & Dimensions & $\begin{array}{c}\text { Sum of } \\
\text { Items }\end{array}$ \\
\hline A & Demographic profile & & 5 \\
\hline B & Independent variables & Family social support & 6 \\
\hline & & Employee engagement & 6 \\
\hline & & Working environment and condition & 6 \\
\hline & & Manager and peer support & 6 \\
\hline & & Development opportunities & 6 \\
\hline C & Mediating variable & Job satisfaction & 6 \\
\hline D & Dependent variable & Employee retention & 6 \\
\hline
\end{tabular}

\section{Instrument Development}

The research instrumentation was in a form of close ended questions that adapted from previous studies (Table 2). The questionnaire was easily understood for the respondents to select the one nearest to their own standpoint. Fixed alternative questions are less time consuming for respondents to complete the questionnaires. The questionnaire was adapted from Bhatia \& Srilatha (2016), Jain \& Nair (2017), Motlou et al., (2016), Rosales et al., (2013) and Razak et al., (2016). In total 47 questions were distributed from Section A to D in this study.

Table 2: Research Instrumentation

\begin{tabular}{|c|c|c|c|}
\hline Section & Dimensions & Count & Items \\
\hline \multirow[t]{30}{*}{$\mathrm{B}$} & \multirow{6}{*}{$\begin{array}{l}\text { Family } \\
\text { social } \\
\text { support }\end{array}$} & 1 & $\begin{array}{l}\text { Someone in my family ask me regularly } \\
\text { about my workday. }\end{array}$ \\
\hline & & 2 & $\begin{array}{l}\text { When I have problem in workplace, my } \\
\text { family member express concern. }\end{array}$ \\
\hline & & 3 & $\begin{array}{l}\text { My family members help me in the } \\
\text { household task. }\end{array}$ \\
\hline & & 4 & $\begin{array}{l}\text { My family give me assistance in dealing } \\
\text { with my work-related issue. }\end{array}$ \\
\hline & & 5 & $\begin{array}{l}\text { My family give me good suggestions to go } \\
\text { through difficult times at work. }\end{array}$ \\
\hline & & 6 & $\begin{array}{l}\text { My family listen to my work } \\
\text { problem or stress. }\end{array}$ \\
\hline & \multirow{6}{*}{$\begin{array}{c}\text { Employee } \\
\text { engagement }\end{array}$} & 7 & I feel like I am being part of this hospital. \\
\hline & & 8 & $\begin{array}{l}\text { Management spends time listening to } \\
\text { nursing employees. }\end{array}$ \\
\hline & & 9 & $\begin{array}{l}\text { I am happy in my autonomy involvement in } \\
\text { decision making. }\end{array}$ \\
\hline & & 10 & $\begin{array}{l}\text { My peers listen to my work } \\
\text { problems. }\end{array}$ \\
\hline & & 11 & I enjoy working with my co-workers. \\
\hline & & 12 & $\begin{array}{l}\text { Generally, I trust my superior and } \\
\text { colleagues. }\end{array}$ \\
\hline & \multirow{6}{*}{$\begin{array}{c}\text { Working } \\
\text { environment } \\
\text { and } \\
\text { condition }\end{array}$} & 13 & My place of work is pleasant. \\
\hline & & 14 & $\begin{array}{l}\text { The environment in the workplace has trust } \\
\text { and friendliness. }\end{array}$ \\
\hline & & 15 & I have too much to do at work. \\
\hline & & 16 & $\begin{array}{l}\text { I am satisfied with the current physical } \\
\text { working conditions. }\end{array}$ \\
\hline & & 17 & $\begin{array}{l}\text { My organisation helps the employees learn } \\
\text { the need job skills. }\end{array}$ \\
\hline & & 18 & $\begin{array}{l}\text { The tools and equipment used in my work } \\
\text { make my job getting easier. }\end{array}$ \\
\hline & \multirow{6}{*}{$\begin{array}{l}\text { Manager and } \\
\text { peer support }\end{array}$} & 19 & My manager cares about my opinions. \\
\hline & & 20 & My manager shows concern on me. \\
\hline & & 21 & $\begin{array}{l}\text { My manager and colleagues give me advice } \\
\text { about problems encountered on my job. }\end{array}$ \\
\hline & & 22 & $\begin{array}{l}\text { My colleagues help me in making work } \\
\text { related decisions. }\end{array}$ \\
\hline & & 23 & $\begin{array}{l}\text { I am encouraged to handle and solve } \\
\text { problem by myself. }\end{array}$ \\
\hline & & 24 & $\begin{array}{l}\text { It is easy to get along and support from my } \\
\text { colleagues. }\end{array}$ \\
\hline & \multirow[t]{6}{*}{$\begin{array}{l}\text { Development } \\
\text { opportunities }\end{array}$} & 25 & $\begin{array}{l}\text { There are opportunities to grow in this } \\
\text { hospital. }\end{array}$ \\
\hline & & 26 & $\begin{array}{l}\text { I have chances of promotion and } \\
\text { advancement in this hospital. }\end{array}$ \\
\hline & & 27 & $\begin{array}{l}\text { My hospital provides training to employees } \\
\text { to achieve better performance. }\end{array}$ \\
\hline & & 28 & $\begin{array}{l}\text { I have received sufficient training in this } \\
\text { hospital to do my job effectively. }\end{array}$ \\
\hline & & 29 & $\begin{array}{l}\text { My involvement in work helps me gain } \\
\text { skill and knowledge. }\end{array}$ \\
\hline & & 30 & $\begin{array}{l}\text { My involvement in work provides me with } \\
\text { a sense of accomplishment. }\end{array}$ \\
\hline
\end{tabular}




\begin{tabular}{|c|c|c|c|}
\hline \multirow[t]{6}{*}{$\mathrm{C}$} & \multirow{6}{*}{$\begin{array}{c}\text { Job } \\
\text { satisfaction }\end{array}$} & 31 & I do feel the work that I do is appreciated. \\
\hline & & 32 & I am satisfied with management support. \\
\hline & & 33 & $\begin{array}{l}\text { My involvement in my work help me feel } \\
\text { personally fulfilled. }\end{array}$ \\
\hline & & 34 & I will be praised if I over perform my work \\
\hline & & 35 & I am satisfied with my work. \\
\hline & & 36 & $\begin{array}{l}\text { In summary, I am very satisfied working in } \\
\text { this company. }\end{array}$ \\
\hline \multirow[t]{6}{*}{$\mathrm{D}$} & \multirow{6}{*}{$\begin{array}{l}\text { Employee } \\
\text { retention }\end{array}$} & 37 & When I get up, I feel like going to work. \\
\hline & & 38 & $\begin{array}{l}\text { The morale I my unit is very high and my } \\
\text { team are always happy. }\end{array}$ \\
\hline & & 39 & $\begin{array}{l}\text { I always looking forward to the next } \\
\text { working day. }\end{array}$ \\
\hline & & 40 & This job offers me long term security. \\
\hline & & 41 & $\begin{array}{l}\text { I will recommend other nurses working in } \\
\text { this hospital. }\end{array}$ \\
\hline & & 42 & I will not think in leaving this job. \\
\hline
\end{tabular}

\section{RESULTS AND DISCUSSION}

\section{Demographic Profiles}

Demographic information and reliability test result were generated and analysed via IBM SPSS version 23.0 after gathered all the 30 questionnaires from the subjects. Demographic data were obtained in the survey as it helps to identify the characteristics of the small-scale sample in the findings. The demographic variables from the pilot study conducted was summarised in Table 3 .

\section{Table 3: Demographic Information}

\begin{tabular}{|c|c|c|c|}
\hline Demographic Variables & Frequency & $\begin{array}{c}\text { Percent } \\
(\%)\end{array}$ & $\begin{array}{l}\text { Cumulative } \\
\text { Percent (\%) }\end{array}$ \\
\hline $\begin{array}{l}\text { Gender: } \\
\text { Female } \\
\text { Male }\end{array}$ & $\begin{array}{c}30 \\
0\end{array}$ & $\begin{array}{c}100 \\
0\end{array}$ & 100 \\
\hline $\begin{array}{l}\text { Race: } \\
\text { Chinese } \\
\text { Malay } \\
\text { Indian } \\
\text { Others } \\
\end{array}$ & $\begin{array}{c}0 \\
15 \\
10 \\
5 \\
\end{array}$ & $\begin{array}{c}0 \\
50 \\
33.3 \\
16.7 \\
\end{array}$ & $\begin{array}{c}0 \\
50 \\
83.3 \\
100 \\
\end{array}$ \\
\hline $\begin{array}{l}\text { Age: } \\
30 \text { years old and below } \\
31-40 \text { years old } \\
41-50 \text { years old } \\
\text { Above } 50 \text { years old }\end{array}$ & $\begin{array}{c}21 \\
8 \\
1 \\
0 \\
\end{array}$ & $\begin{array}{c}70 \\
26.7 \\
3.3 \\
0\end{array}$ & $\begin{array}{c}70 \\
96.7 \\
100\end{array}$ \\
\hline $\begin{array}{l}\text { Nursing working } \\
\text { experience in the current } \\
\text { hospital: } \\
1 \text { month }-5 \text { years } \\
6-10 \text { years } \\
11-15 \text { years } \\
\text { More than } 15 \text { years }\end{array}$ & $\begin{array}{c}20 \\
7 \\
3 \\
0\end{array}$ & $\begin{array}{c}66.7 \\
23.3 \\
10 \\
0\end{array}$ & $\begin{array}{c}66.7 \\
90 \\
100\end{array}$ \\
\hline $\begin{array}{l}\text { Average working hours } \\
\text { per day: } \\
7-10 \text { hours } \\
11-13 \text { hours } \\
14-16 \text { hours } \\
\text { More than } 16 \text { hours }\end{array}$ & $\begin{array}{c}22 \\
6 \\
1 \\
1 \\
\end{array}$ & $\begin{array}{c}73.3 \\
20 \\
3.3 \\
3.3 \\
\end{array}$ & $\begin{array}{c}73.3 \\
93.3 \\
96.7 \\
100\end{array}$ \\
\hline
\end{tabular}

About $100 \%$ of the registered nurses were female. Majority of them were Malay in their races $(50 \%, n=15)$, followed by Indian $(33.3 \%, \mathrm{n}=10)$ and followed by others $(16.7 \%, \mathrm{n}=5)$. As for the ranging of age, most of them 30 years old and above $(70 \%, \mathrm{n}=21 \%)$, followed by $31-40$ years old $(26.7 \%, \mathrm{n}=8)$ and $41-50$ years old $(3.3 \%, \mathrm{n}=1)$. None of them above 50 years old.
With regards to the nursing working experience in the current hospital, $66.7 \%(\mathrm{n}=20)$ of the respondents had 1 month until 5 years, $23.3 \%(\mathrm{n}=7)$ of them already work from 6 to 10 years and $10 \%(n=3)$ had work from 11 to 15 years in the current hospital. However, none of them work more than 15 years in the medical surgical wards.

In term of average working hours per day, $73.3 \%$ $(n=22)$ of the respondents work in between 7 to 10 hours and $20 \%(n=6)$ of them fall in between 11 to 13 hours. Simultaneously, 3.3\% $(\mathrm{n}=1)$ reaching 14 to 16 hours and more in their average working hours per day.

\section{Reliability Analysis}

Cronbach's alpha is a measure of the internal consistency or reliability between several items, measurements or rating to estimate how reliable are the responses of a questionnaire that evaluated by subjects to identify the stability of the tools (Bujang et al., 2018). The value of Cronbach's alpha ranges from zero to one with higher level indicating the items are measuring the same dimension and if the value is low or near to zero, it indicates all the items are not measuring the same dimension (Bujang et al., 2018). The result of the reliability analysis was summarised in Table 4.

\section{Table 4: Reliability Test Result}

\begin{tabular}{|l|c|c|}
\hline \multicolumn{1}{|c|}{ Construct } & Number of Items & $\begin{array}{c}\text { Cronbach's Alpha } \\
\text { Value }\end{array}$ \\
\hline Family social support & 6 & 0.936 \\
\hline Employee engagement & 6 & 0.882 \\
\hline $\begin{array}{l}\text { Working environment and } \\
\text { condition }\end{array}$ & 6 & 0.893 \\
\hline Manager and peer support & 6 & 0.919 \\
\hline Development opportunities & 6 & 0.950 \\
\hline Job satisfaction & 6 & 0.938 \\
\hline Employee retention & 6 & 0.904 \\
\hline All constructs & 42 & 0.972 \\
\hline
\end{tabular}

Development opportunities reached the highest Cronbach's $\alpha=0.950$, followed by job satisfaction (Cronbach's $\alpha=0.938$ ), family social support (Cronbach's $\alpha=0.936$ ), manager and peer support (Cronbach's $\alpha=0.919$ ), employee retention (Cronbach's $\alpha=0.904$ ), employee engagement (Cronbach's $\alpha=0.882$ ) and working environment and condition (Cronbach's $\alpha=0.893$ ). The overall constructs Cronbach's $\alpha=0.972$. All the Cronbach's $\alpha$ value were acceptable and had high level of internal consistency that allowed to proceed for actual study as Cronbach's $\alpha$ acceptable value should be above 0.70 (Tayakol \& Dennick, 2011). No items were required to be amended or dropped.

Engaged workers are more inspired, energetic, have a better connectivity with their jobs, and able to manage productively towards the work demands (Othman \& 
Nasurdin, 2019). Work related support from superior and peers act as the core elements of social support that can relate in burnout (Sellar et al., 2019). A leader with high concern for her subordinates has been found to contribute more employees' satisfaction as both can feel the respect and warm relationship (Irabor \& Okolie, 2019). The nature of connections including communication between the boards and nursing personnel impacts the workers themselves as well as affect organizational effectiveness by influencing productivity and turnover rates (Brunetto et al., 2014). Job contentment depicts contented level of an employee with their job and it is part of life satisfaction (Irabor \& Okolie, 2019). It is essential to ensure employees job satisfaction is at the maximum level to improve work happiness and subsequently lead to retention (Hee et al., 2019). Employees who perceive they are being treated satisfactory within their organisational contributions will perform within meeting expectation level and tend to remain in the same organisation (Avanzi et al., 2014). Employee satisfaction has a direct relation on behaviour in the workplace and with good rating of employee satisfaction, it will improve the retention rate among workers (Abuhashesh et al., 2019). Nursing administration should increase their focus on developing strategies to assist and encourage junior administrative to strengthen the career prospects and increase satisfaction level within individual (ChiouFen et al., 2019).

\section{CONCLUSION}

The study had designed a survey questionnaire using five-point Likert scale and disseminated to 30 registered nurses working in medical surgical wards in one of the tertiary hospitals in Kuala Lumpur, Malaysia as a pilot study. Instrument development, descriptive and reliability analysis process were explained. $100 \%$ of the registered nurses were female and most of them were Malays $(50 \%, \mathrm{n}=15)$. Majority of their working experience were in between 1 month to 5 years $(66.7 \%$, $\mathrm{n}=20)$ and $73.3 \%(\mathrm{n}=22)$ average working in between 7 10 hours per day. The Cronbach's $\alpha$ of each and overall construct ranging in between 0.882 to 0.972 . All the values showed high level of internal consistency.

Employee retention is a challenging issue for most of the developed and developing countries. Previous studies revealed that it is mainly focused on recruitment and selection activities of nurses. Moreover, it is important to attract and retain more dedicated and quality professional nursing staff. Considerable studies have established that job satisfaction as a main predictor of turnover intention. Therefore, it is crucial to identify significant predictors of job satisfaction which will consequently reduce turnover intention among staff nurses in Malaysia healthcare industry.

\section{Conflict of Interests}

The authors declare that they have no conflict of interest.

\section{ACKNOWLEDGEMENT}

We would like to extend a special thank you to all who had assisted us in this study and especially the Ethics Committee team to facilitate in this research.

\section{REFERENCES}

Abuhashesh, M.,Al-Dmour, R. \& Masa'deh, R. (2019). Factors that affect employees job satisfaction and performance to increase customers'satisfactions. Journal of Human Resources Management Research, 2019, pp 1-23.

Antwi, Y.A. \& Bowblis, J.R. (2018). The impact of nurse turnover on quality of care and mortality in nursing homes: evidence from the great recession. American Journal of Health Economics, 4(2), pp 131-163.

Avanzi, L., Fraccaroli, F., Sarchielli, G., Ullrich, J. \& van Dick, R. (2014). Staying or leaving, a combined social identity and social exchange approach to predicting employee turnover intention. International Journal of Productivity and Performance Management, 63(3), pp 272-289.

Bhatia, Y. \& Srilatha, S. (2016). Impact of family support on job involvement in women professionals in India. Journal of Business Management \& Social Sciences Research, 5(5), pp 147-154.

Bobbio, A. \& Manganelli, A.M. (2015). Antecedents of hospital nurses' intention to leave the organization: A cross sectional survey. International Journal of Nursing Studies, 52(7), pp 1180-1192.

Brunetto, Y., Shacklock, K., Teo, S. \& Farr-Wharton, R., 2014. The impact of management on the engagement and well- 
being of high emotional labour employees. The International Journal of Human Resource Management, 25(17), pp 2345-2363.

Bujang, M.A., Omar, E.D. \& Baharum, N.A. (2018). A review on sample size determination for Cronbach's alpha test: a simple guide for researchers. The Malaysian Journal of Medical Sciences: MJMS, 25(6), p 85.

Chiou-Fen, L.I.N., Huang, C.I., Che-Ming, Y.A.N.G. \& Meei-Shiow, L.U. (2019). The relationship between work environment satisfaction and retention intention among nursing administrators in Taiwan. The Journal of Nursing Research, 27(5), p e43.

Fraser, J., Fahlman, D., Arscott, J. \& Guillot, I. (2018). Pilot Testing for Feasibility in a Study of Student Retention and Attrition in Online Undergraduate Programs. International Review of Research in Open and Distributed Learning, 19(1), pp 260-278.

Hee, O. C., Ong, S. H., Ping, L. L., Kowang, T. O. \& Fei, G. C. (2019). Factors Influencing Job Satisfaction in the Higher Learning Institutions in Malaysia. International Journal of Academic Research in Business and Social Sciences, 9(2), pp 10-20.

Irabor, I. E. \& Okolie, U. C. (2019). A Review of Employees' Job Satisfaction and its Affect on their Retention. Annals of Spiru Haret University. Economic Series, 19(2), pp 93 - 114.

Jain, S. \& Nair, S. K. (2017). Work Support and Family Support as Predictors of Work-to-family Enrichment and Familyto-work Enrichment. Global Business Review, 18(5), pp 1307-1324.

Motlou, R. G., Singh, S. \& Karodia, A. M. (2016). An Evaluation of the Impact of Job Satisfaction on Employee Retention at Lonmin Rowland Shaft North West Province. Kuwait Chapter of Arabian Journal of Business and Management Review, 5(10), pp 15-49.

Othman, N. \& Nasurdin, A. M. (2019). Job characteristics and staying engaged in work of nurses: Empirical evidence from Malaysia. International Journal of Nursing Sciences, 6(4), pp 432-438.

Permarupan, P.Y., Al Mamun, A., Samy, N.K., Saufi, R.A. \& Hayat, N. (2020). Predicting nurses burnout through quality of work life and psychological empowerment: A study towards sustainable healthcare services in Malaysia. Sustainability, 12(1), p 388.

Razak, N.A., Ma'amor, H. \& Hassan, N. (2016). Measuring reliability and validity instruments of work environment towards quality work life. Procedia Economics and Finance, 37(16), pp 520-528.

Rosales, R.A., Labrague, L.J. \& Rosales, G.L. (2013). Nurses' Job satisfaction and Burnout: Is there a connection? International Journal of Advanced Nursing Studies, 2(1), p 1.

Sellar, T., Arulrajah, A.A. \& Lanka, V. (2019). The Role of Social Support on Job Burnout in the Apparel Firm. International Business Research, 12(1), pp 110-118.

Tavakol, M. \& Dennick, R. (2011). Making sense of Cronbach's alpha. International Journal of Medical Education, 2 , p 53. 